\title{
TBK1 wt Allele
}

National Cancer Institute

\section{Source}

National Cancer Institute. TBK1 wt Allele. NCI Thesaurus. Code C51328.

Human TBK1 wild-type allele is located in the vicinity of $12 q 14.1$ and is approximately 50 $\mathrm{kb}$ in length. This allele, which encodes serine/threonine-protein kinase TBK1 protein, is involved in the innate immune response and mediation of transcription factor NF-kappa$B$ activation in response to certain growth factors. 